\title{
Shaping a Critical Study Abroad Engagement through Experiential Arts-Based Inquiry
}

\section{ABSTRACT}

Study abroad $(\mathrm{SA})$ is often equated to cultural learning, which is problematic when culture is presented as a fixed concept free of context. To challenge cultural labeling and develop students' critical consciousness, this study implemented an arts-based inquiry intervention within a United States (US) SA program in Italy. Using a Deweyan experiential frame it incorporated arts-based pedagogy, which refers to the artistic tools and strategies used to support and stimulate students' reflective learning. This qualitative case study describes the process of 13 undergraduate US students' participation in a multi-phase inquiry project as a scaffold for educators and illuminates the complexity of learning through participants' art and reflections. Findings suggest the inclusion of arts-based inquiry can support the development of critical consciousness of "cultural hybridity" and can decenter students' assumptions and perspectives to feature the voices of those around them. Additionally, the article highlights that the learning process is both complex and continual. It indicates that scholar practitioners must be aware of the potential for essentialization through representation, and therefore the need to continue to address cultural stereotypes while also guiding students to examine their own understandings of self and culture. The paper concludes with recommendations for continued improvement and implications for both the international field of SA and for educators in general who seek to expand critical thinking and meaning-making in the classroom.

\section{KEYWORDS}

study abroad, cultural hybridity, arts-based pedagogy, John Dewey, experiential

\section{INTRODUCTION}

Cultural stereotypes not only precede SA experiences (Ngyuen and Coryell 2015), students often continue to make assumptions and then draw conclusions from their experiences abroad (Ladegaard, 2020; Michelson and Álvarez Valencia 2016). Moreover, culture is often presented through fixed snapshots in textbooks, guidebooks, or from educators themselves. Nieto (2017) stressed, "When culture is presented to students as if it were context-free, they learn to think of it as quite separate from the lives that people lead every day" (139). Brewer, Beaudin, and Woolf (2019) emphasized the responsibility of SA educators to challenge students to critically engage beyond their home experiences and familiar norms to consider culture through "new ideas in new places" (66). SA educators continually point to the need for intervention to dismantle assumptions, stereotypes, and static representations of culture (Bain and Yaklin 2019; Goldoni 2015; Moreno 2021) often highlighting experiential learning strategies (Mabingo 2019; Powers et al. 2020; Strange and Gibson 2017) including critical reflection 
(Elverson and Klawiter 2019; Hamilton et al. 2019) and guided facilitation from SA providers and teachers (Cai and Sankaran 2015; Moak 2020).

There is clear connection to John Dewey's ([1938] 1998) theory of experience in contemporary SA with its focus on purposeful curricular design and critical reflection (see Pipitone 2018; Vande Berg, Paige, and Lou 2012). Rennick (2015) highlighted Dewey's educational perspectives alongside those of Paolo Freire and Jack Mezirow in an argument for creating a critical, participatory, and experiential SA pedagogy. Yet, despite the relevance of Dewey's work to SA, the explicit application of his theories is largely absent in the research with only a small group of scholars framing their work with a Deweyan lens (e.g., Breunig 2017; DiFrancesco et al. 2019; Hayes 2020; Sharma, Phillion, and Malewski 2011).

I looked to Dewey's ([1938] 1998) theory of experience as both a theoretical and conceptual framework for this study while guided further by Dewey's ([1934] 2005) views on art as a means for educational inquiry. Grounded in the scholarship of teaching \& learning (SoTL) and literature in the field (see Moreno 2021), this study engaged in an interactive conversation between theory, research, and teaching practice. Following SoTL principles (see Bernstein 2018; Felten 2013), I used case study to provide a rigorous methodological approach for internal and external validity to systematically analyze what works in the learning intervention, while also presenting a rich description to guide educators in the larger field. I qualitatively explored the experiences of 13 US undergraduate students in a short-term SA program in Italy as they participated in an arts-based experiential intervention within my Italian language and culture course. While the findings are specific to this case study, they lend themselves to the larger global field of SA to inform international educators teaching across borders. The intervention is additionally relevant to the broader educational context and can be adapted to fit varied curricula to support expanded and critical meaning-making.

As the instructor, my objective was to disrupt the idea of culture as a static set of labels absent of any individualized contextual nuances by having students engage in a critical examination of their own understandings of Italian "culture" through photography, reflection, and the creation of an artistic piece in a medium of choice. Through experiential inquiry, students would engage with culture in a hybrid space to reconceptualize it as highly complex and contextualized within the local community, but also within the more abstract in-between space introduced by Homi Bhabha (1994). Following applied linguists and scholars of interculturality (see Kramsch and Uryu 2020), I borrow Bhabha's term "cultural hybridity" to explore intercultural growth in the SA setting. Rather than relying on the array of "cultural learning" terms that can position culture as fixed, this term reframes the learning process as a hybrid notion that exists in a continual space of movement and change. With this framework, the following research questions guided this case study:

What are the effects of a pedagogical experiential learning intervention on student awareness and interpretation of cultural hybridity in a SA program? In what ways do research-through-art and art making impact students' reflections on cultural variability and complexity?

\section{ART AS EXPERIENCE}

Thinking through and with art is supported by Dewey's ([1934] 2005) views of art as a means to develop consciousness. Dewey (1926) often referred to consciousness as the notion of "being wideawake, alert, [and] attentive to the significance of events, present, past, future" (298). In this view, art is 
not a mere object, it is instead an experience gained from either the process of creating the art or the act of encountering it. The "doing" of art encompasses a reflective process that impacts perception. Dewey maintained that art is embodied inquiry where meaning-making occurs through the experience of production where "the artist does his thinking in the very qualitative media he works in" ([1934] 2005, 15). Elliot Eisner (2002), a Deweyan-informed, arts-based researcher, spoke to the use of art as a source for "transforming consciousness" since "the senses are our first avenues to consciousness" (1-2).

Arts-based researchers have looked to art as a mode of scientific inquiry to qualitatively reflect on and interpret their research (Barone and Eisner 2012; Cahnmann-Taylor and Siegesmund 2017). Dewey's theory of art is foundational to contemporary arts-based frameworks where art is re-imagined as both thinking and methodology (Siegesmund 2012). Sousanis (2017), a comics-based researcher, described art as a venue for "thinking you can[not] do otherwise" (193) and "art-making as investigation" (198). Arts-based researchers embrace the idea that meaning-making and understanding flourish in artistic production while also recognizing that subjectivity and positionality play an active role in their interpretations and perceptions.

\section{Art for critical cultural reflection}

Working through artistic processes expands the possibility to penetrate cultural biases and dominant discourses to better see lived experiences beyond their own (Greene 1995). Varga-Dubai (2018) used "Cultural Selfies" as an arts-based multimodal self-reflection project with pre-service teachers to critically explore constructions of culture and identity. White (2018) developed an anti-bias educational program for college students based on the performance of "The Dance" accompanied by guided critical reflection to confront racial and ethnic stereotyping. Black and Bernardes (2012) likewise used performance, but in the SA context. Using drama and role play in a SA program in Kenya, Black and Bernardes concluded that arts-based activities served as the "necessary vehicles" (101) to critically reflect on power and privilege while challenging their assumptions of their experiences. Rodríguez (2006) found the combination of poetic writing and group critical reflection to be a means to help stimulate US students' reflective process on issues of cultural (mis)representation, power, and privilege while studying in Mexico. Participants engaged with considerations of "othering" through the creative writing of their experiences from various viewpoints, including those in the community and even inanimate objects such as the city garden. In doing so, Rodríguez found students became more aware of the local people who had previously gone unnoticed as part of the backdrop, such as a woman selling hotdogs.

Mabingo (2019), on the other hand, found that although experiential art brought deeper attention to cultural differences in their study, it also highlighted the potential for appropriation and othering. Mabingo explored six US students' perceptions of culture, difference, and place through the learning and embodiment of dance in a SA program in Uganda and determined that the meaningmaking process surrounding topics of culture is both complex and complicated by one's positionality. Mabingo argued educators need to dive deeper into critical work with SA and arts-based pedagogy.

\section{METHODS}

Informed by a social constructionist paradigm, Dewey's theory of experience, and my identity as a scholar-practitioner, I used a qualitative case study to explore the impact of an arts-based pedagogical 
intervention within my own course during a summer SA program. Teacher educators, Lytle and Cochran-Smith $(1992,448)$ have long argued for the benefit of teachers conducting intentional and systematic research in their own classrooms as a way of knowing. SoTL scholar, Nancy Chick (2014) added, "Projects that offer a solution to a problem or demonstrate the effectiveness of a strategy are particularly attractive" (4). This case study, therefore, presents both the methodological approach and detailed description of the intervention to ensure trustworthiness and guide future practice (Merriam 1998).

\section{Context and participants}

The case for this research study is bounded within the context of an eight-week, higher education SA program in Italy that occurred in June and July of 2018. It was comprised of a group of 13 US, four-year undergraduate students enrolled in my elementary Italian language course with attention to their individual experiences with the inquiry project. These students were part of a larger program of 85 students from a large, southeastern US university. The program took place in the small town of Montesole (pseudonym).

The majority of class participants identified as white and female as highlighted in table 1 . Ten students were from large metropolitan cities and three were from small and/or rural towns all within the same southern state. The students were largely in their third year of study and all had varied academic majors; only two had a background in art. My course was their first formal exposure to Italian language and culture. All but two students had traveled internationally before, but primarily to resort destinations, English speaking countries, or common tourist destinations in Europe such as Paris and Florence.

Table 1. Participant profiles

\begin{tabular}{|c|c|c|c|c|}
\hline Names* & $\begin{array}{c}\text { Rising school } \\
\text { year }\end{array}$ & Major & Gender & Race/ ethnicity \\
\hline Carolann & $3^{\text {rd }}$ year & Public relations & Female & White \\
\hline Annie & $3^{\text {rd }}$ year & Management information systems & Female & White \\
\hline Isabelle & $3^{\text {rd }}$ year & Marketing & Female & White \\
\hline Kenna & $3^{\text {rd }}$ year & Public relations & Female & White \\
\hline Charlotte & $3^{\text {rd }}$ year & Accounting & Female & White \\
\hline Joelie & $3^{\text {rd }}$ year & Journalism & Female & White \\
\hline Dannie & Graduating & Landscape architecture & Female & White \\
\hline James & $4^{\text {th }}$ year & Economics & Male & White \\
\hline Katy & $2^{\text {nd }}$ year & Genetics & Female & White \\
\hline Riley & $3^{\text {rd }}$ year & Chemistry & Female & White \\
\hline Mia & $3^{\text {rd }}$ year & Biological science & Female & White \\
\hline Noah & $3^{\text {rd }}$ year & Computer science & Male & $\begin{array}{l}\text { Filipino- } \\
\text { American }\end{array}$ \\
\hline Sara & $4^{\text {th }}$ year & Psychology & Female & White \\
\hline
\end{tabular}




\section{Data collection and analysis}

In alignment with the case study, data collection included a variety of sources for triangulation (Merriam 1998), specifically: individual interviews, a focus group, questionnaires, observations, social media posts, as well as course work including blog entries, photographs, reflective essays, class and oneon-one discussions, personalized tours, and artistic creations. Data collection occurred primarily on-site during the program, however, semi-structured interviews ranging from 55-90 minutes took place a year later to better understand the long-term impact of the participants' experiences along what Dewey termed the "experiential continuum" ([1938] 1998, 17)

\section{Visual review}

Within the interviews I also employed a visual review method. I showed digital images of student artistic creations and asked participants to walk me through their thought process for creating the pieces. This visual review served as a member check for my interpretations of their artistic creations and inquiry process. Participants brought my attention to specific details and intentionality that I had not noticed such as purposeful materials or particular colors used to highlight emotion.

\section{Analysis}

Data analysis was thematic in nature using both deductive and inductive coding. I iteratively reviewed the data and organized coding and memos using the qualitative data analysis software MAXQDA 2018. Further data reduction and interpretation continued through the physical mapping and layering of artifacts and codes to understand emergent themes. During analysis, the themes also led to my own reflexivity regarding my role as the teacher and researcher.

\section{A DESCRIPTION OF THE ARTS-BASED INTERVENTION}

In conjunction with learning the Italian language, students simultaneously engaged in cultural inquiry projects. I asked my students to become artist-researchers by using art and qualitative methods as tools for their own cultural inquiry. I conceptually followed Dewey's $(1933,218)$ criteria for scaffolding experiential learning projects: 1) generate the individual's interest, 2) be intrinsically worthwhile, 3) present problems that stimulate curiosity, and 4) cover a considerable amount of time to foster a continuity of experiences. Instead of giving students an inquiry topic, I brought them into the conversation by having them generate their own based on their curiosity and experiences studying abroad in Italy up to that point. The students met with me individually to discuss their projects, which gave me a better idea of where they were starting in their process and what their initial thoughts of their topics were. I approved each of their topics even if I felt them to be cliché because the intention was for them to work through initial assumptions through their inquiry project. Table 2 presents an overview of the students' projects with a brief description of why they chose their initial topics along with a visual of their final creations. 
Table 2. Overview of the students' cultural inquiry projects

\begin{tabular}{|c|c|c|c|}
\hline Name & $\begin{array}{c}\text { Cultural inquiry } \\
\text { topic }\end{array}$ & Brief description & Artistic representation \\
\hline Charlotte & $\begin{array}{l}\text { Coffee } \\
\text { Culture }\end{array}$ & $\begin{array}{l}\text { I decided that I wanted to focus on what made Italian } \\
\text { coffee culture different from American coffee culture. } \\
\text { The idea that you should never order a cappuccino or } \\
\text { a latte after lunch was so funny to me. [I assumed] } \\
\text { that all Italians drank coffee three times a day and they } \\
\text { always drank their coffee with friends. }\end{array}$ & \\
\hline Kenna & $\begin{array}{l}\text { Grocery } \\
\text { Shopping: } \\
\text { The Fruit } \\
\text { Stand }\end{array}$ & $\begin{array}{l}\text { While being in Montesole, I have thoroughly enjoyed } \\
\text { grocery shopping, specifically for fruit } \\
\text {.. Because I have experience at grocery shopping in } \\
\text { [my city back home], I decided to look at the } \\
\text { difference between shopping for fruit produce } \\
\text { in Montesole compared to [home]. }\end{array}$ & \\
\hline Mia & The Steps & $\begin{array}{l}\text { The reason I chose this topic is because it was so } \\
\text { interesting to me that so many people would come to } \\
\text { the steps every day and simply sit and talk for hours. }\end{array}$ & \\
\hline Noah & $\begin{array}{c}\text { Unspoken } \\
\text { Rules }\end{array}$ & $\begin{array}{l}\text { I asked, "how do locals really feel about unwritten } \\
\text { cultural rules [ such as: one does not eat and walk] and } \\
\text { how do they react when they are broken?" }\end{array}$ & \\
\hline Joelie & $\begin{array}{l}\text { Wine } \\
\text { Culture }\end{array}$ & $\begin{array}{l}\text { Upon arriving here, my first instinct was to drink my } \\
\text { glasses of wine fast in order to feel them more, but as I } \\
\text { saw what others were doing around me, I realized that } \\
\text { wasn't the culture here. }\end{array}$ & \\
\hline
\end{tabular}




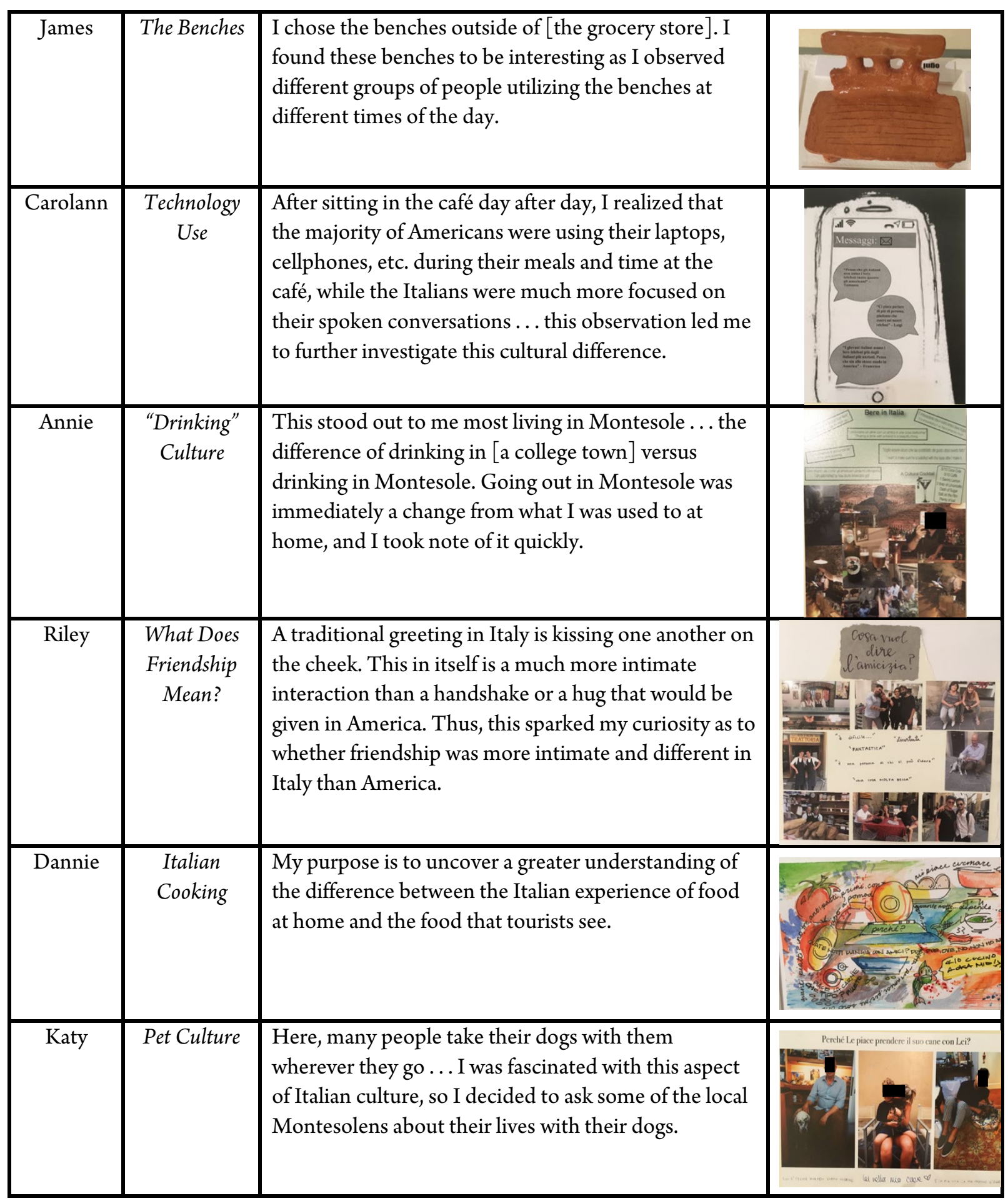




\begin{tabular}{|c|c|c|c|}
\hline Isabelle & $\begin{array}{c}\text { Artisan } \\
\text { Product } \\
\text { Production }\end{array}$ & $\begin{array}{l}\text { Montesole is filled with tourists just like many other } \\
\text { cities in Italy. This made me curious about the artisan } \\
\text { shops, so I decided to interview the shop owners to } \\
\text { get their opinion on tourists and who they actually try } \\
\text { to make their products for. }\end{array}$ & 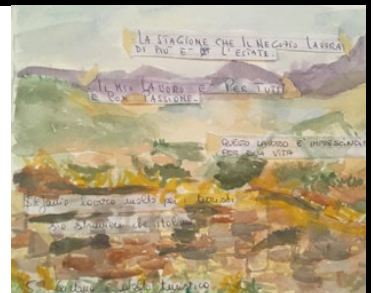 \\
\hline Sara & $\begin{array}{c}\text { Personal } \\
\text { Space }\end{array}$ & $\begin{array}{l}\text { I noticed Italians always seemed to be close to one } \\
\text { another as they are speaking. I then began to pay } \\
\text { attention to this behavior and noticed that Italians } \\
\text { seemed to have a smaller personal bubble compared } \\
\text { to what I had been conditioned to maintain as an } \\
\text { American. }\end{array}$ & $\begin{array}{c}\text { Mi piac } \\
\text { Mo } \\
\text { parli } \\
\text { Parla }\end{array}$ \\
\hline
\end{tabular}

I created multiple project phases (see table 3) that took place in weeks three to six of the course that would not only continue to build curiosity, but also allow for reflective continuity between experiences. I embedded reflection into each phase through class discussion, one-on-one discussions with me, blog writing, a reflective essay, and the artistic process itself. I asked students to take a minimum of 10 photos on the same topic at different times of day and in different locations if possible, and to then analyze across their photographs. I instructed them to notice the time of day, the use of space, what was going on in the periphery, the types of interactions, and who was and was not represented. Following analysis of their photographs, the students created interview protocols in Italian and conducted three interviews using the extent of their Italian knowledge. They filled in the gaps of communication in English when possible. Students further engaged in written reflections and the making of an artistic creation to continue their analysis and represent how they understood their cultural topic. Participants shared their projects with the community and their peers in the SA program's culminating art show. 
Table 3. Cultural inquiry project

\begin{tabular}{|c|c|}
\hline \multirow{3}{*}{$\begin{array}{l}\text { Project phases } \\
\text { Phase 1: } \\
\text { Initial inquiry and } \\
\text { observations }\end{array}$} & Phase components \\
\hline & -Written response to: "What does Italian culture mean to you?" \\
\hline & -Initial observations to determine project topic \\
\hline \multirow{2}{*}{$\begin{array}{l}\text { Phase 2: } \\
\text { Photo observation } \\
\text { series and analysis }\end{array}$} & -Series of photos (minimum of 10 ) on the same topic \\
\hline & -Analysis of photos looking for similarities and anomalies \\
\hline \multirow[t]{2}{*}{ Phase 3: Interviews } & -Develop interview guides based on their analysis \\
\hline & -Interviews (minimum of three) within the community \\
\hline \multirow{2}{*}{$\begin{array}{l}\text { Phase 4: Artistic } \\
\text { creations }\end{array}$} & -Create artistic representation of topic using choice of medium \\
\hline & -Write project descriptions \\
\hline $\begin{array}{l}\text { Phase 5: } \\
\text { Art exhibition }\end{array}$ & -Display projects in program art show. \\
\hline $\begin{array}{l}\text { Phase 6: } \\
\text { Final reflection }\end{array}$ & -Final reflective essay on their experiences with the project \\
\hline
\end{tabular}

\section{Mia's project as an example}

I use Mia's project, “The Steps,” to showcase the flow of the inquiry process. When initially asked about Italian culture before the start of the program, Mia brought up food and the sights. Throughout our class, we problematized categorizing culture only as "things" and I asked students to instead approach the inquiry project with an open exploratory lens of place, people, beliefs, and ideas, based on what they noticed — or did not notice - around them.

In phase 1, Mia chose to focus on the city hall steps in the town center because she spent a lot of time there with friends eating gelato. In doing so, she noticed that "people would come to the steps every day and simply sit and talk for hours." This piqued Mia's curiosity about social spaces in the small Italian town in comparison to the small southern US town where she grew up.

In phase 2, Mia next took pictures of the steps at different times of day and on different days. The following four photos in figure 1 are a sample from her larger series. Mia then analyzed her photos and found that the same group of older men was in almost each one, which prompted her to shift her topic to focus specifically on the social practices of this group of men.

She questioned, "how long they had been sitting on those exact steps, and if they ever changed where they sit or the time or day that they sit." 
Figure 1. Four photos from Mia's photo observations series
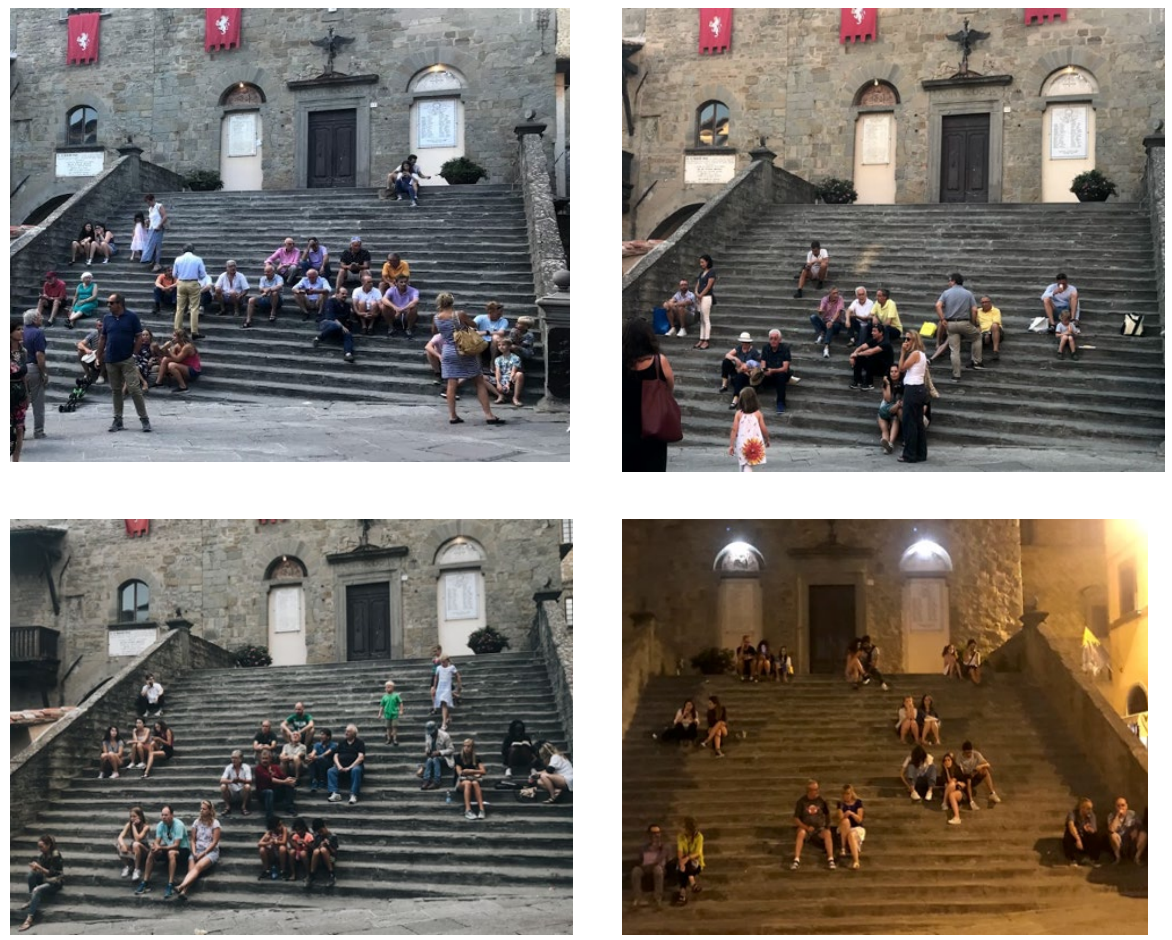

In Phase 3, Mia interviewed the men to ask about their social habits and they explained they had been coming to the steps almost every day for years to sit and "just be present" together. In Phase 4, she created a three-dimensional representation of the steps (see figure 2) to emphasize the steps as a social space for this group of men and her growing understanding that "culture" can also include daily practices and can be specific to individuals and small groups rather than the broad labels she had initially assigned. Mia used paper folding as her medium because she felt she had "no artistic talent," but knew she "could cut paper." She added highlighting in watercolor "to give [the steps] more depth." Mia felt that doing so emphasized their cultural purpose as a foundation for socialization where people like the older men could congregate. 


\section{Figure 2. "The steps" by Mia}

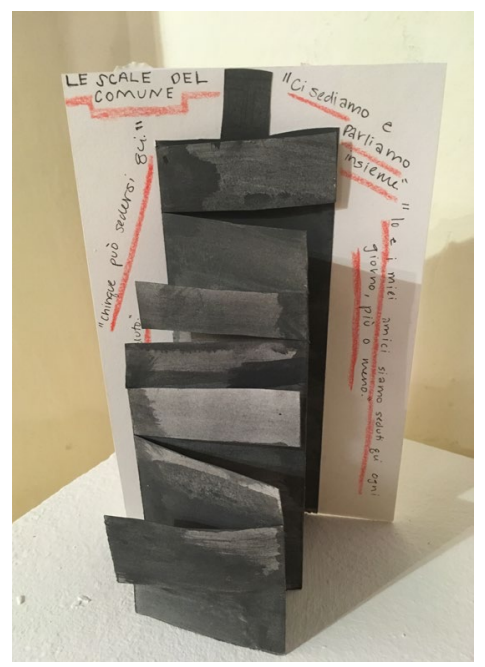

In Phase 5, the art exhibition served as a platform for cultural discussion. Other students had not necessarily thought about the steps as a piece of living "culture" before. One expressed, "Oh, that's cool! I never thought about the stairs like that." Mia's inclusion of quotes from the older men also brought attention to their social existence, which proved surprising to some of her peers who-despite walking past the steps everyday-had not noticed them.

Mia's case serves as an example of the overall process and how students generally moved through the phases detailed in table 3 . As will be discussed further, the process served as a point of departure to help students begin to notice, or develop "consciousness" of, what was occurring around them beyond their personal SA experiences and to consider new conceptualizations of what "culture" can entail. Nevertheless, as the findings will show, students would have benefitted from additional phases of increased guided critical reflection and discussion with the instructor and the incorporation of varied cultural discourses to challenge them to go deeper into the nuanced nature of "culture."

\section{FINDINGS}

Returning to the guiding research questions, four overarching themes emerged from the data: developing consciousness, (de)centering the student perspective, art-as-thinking, and art-asrepresentation.

\section{Developing "consciousness"}

This theme arose from a combination of codes related to noticing and awareness of what was going on beyond students' personal bubbles - not only in terms of noticing, but also with what they were noticing. In Mia's case above, she had not previously noticed the group of older men who sat on the steps every day until reviewing her photo observations. The project helped students begin to hone their observational skills and develop Dewey's conceptualization of "consciousness" where they became more conscious and reflective of things they may not have noticed before. Noah, for example, felt that the project forced him to remember to notice. He realized he had not been paying attention to what was going on around him: 
I feel like I wasn't observing the way that I usually observe in daily life. I'm usually much better at that. I guess I was kinda on a joy ride but then... I started looking and I started asking and I was like whooaaa...

The inquiry project pushed Noah to "start looking" and in doing so he began to see the daily life occurring outside his vacation bubble.

\section{"Capturing a moment in time"}

The use of photography essentially froze scenes of life to give students the time to examine what was happening. Annie noted that the photographs helped her "observe mannerisms and gestures" that she felt had otherwise gone unnoticed during her in-person observations. Mia explained that the photographs brought her attention to a pattern that she had not noticed on her own: "I took pictures at different times and basically no matter what time I took the pictures there were older men there." Noah felt that the photo observations were helpful because they were "capturing a moment in time," because even in the moment he said, "I wasn't even sure what I was taking pictures of ... the photos were crucial." For these students, the photo observation series served as an interactive experience along their experiential continuum. Rather than just continuing on their way, they were guided to stop and notice what was going on around them.

By later examining and analyzing their photos some students engaged in a reflective transaction with the photos and their observations. In discussing his inquiry topic of the benches, James, for example, noted:

Before any of this, I thought they were just seats. I didn't think past them as being seats ...you'd see tourists grab sandwiches and sit there. I started noticing the benches and the old guys sitting on the benches talking. I had noticed them before, but I hadn't given any thought to what they were doing.

As part of his process of developing consciousness he questioned what the benches might mean beyond just their superficial physical purpose. James examined more than 20 pictures of the benches and realized they were not only a social area for the older Italian men, they were also a glimpse of a larger slice of the Italian lifestyle.

I was looking at the bench and wondering what they do in the time in-between and how does the piazza evolve throughout the day?... I took some [photos] at [3 a.m.], at 7 a.m., in the middle of the afternoon, at 6 p.m., etc. So [my inquiry] started as a bench project and kinda switched into "what do they do there?"

Focusing on the bench brought James's attention to new ways of thinking about "culture" and as he said above, what happens in the "in-between."

While James was not referring intentionally to Bhabha's Third Space (1994), he was starting to consider the idea that culture exists across spaces and labels. James continued that the inquiry project 
made him start to question what he termed the "cultural façade," which is what tourists, or outsiders, struggle to see past. He explained,

What is a cultural façade? This is what foreigners think we do, but what do we actually do? What is "for tourists" versus what do they actually do on a day-to-day basis? It's like finding the stereotypical holes like "oh Italians don't eat between this and this o'clock," but some might actually, based on their schedule.

James felt that the project helped him notice the "stereotypical holes," to see beyond what is normally communicated as "culture." He added,

Doing a project-it was a lot more educational because I feel like in foreign language education there's a lot more of like "this is what they do." Like "this is what Germans do. This is what the French do."

By being part of the process himself, James felt it helped him question culture as a static label to consider cultural complexity.

\section{(De)centering the student perspective}

The multiple phases of the project gave students the time to reflect and consider their inquiries from their hosts' perspectives. The interviews served as a method to involve the voices of the community members and help students avoid what Adkins and Messerly (2019) referred to as the "'traditional' ethnographic trap" (79) where some may rely solely on observation rather than the voices of their participants. Isabelle, Sara, and Dannie, for example, highlighted the opinions of their participants in their pieces and used their words to support findings of variation rather than definitive conclusions.

Riley reframed her inquiry project entirely so that her participants could instead speak for themselves rather than her guiding the project with her own assumptions. She had initially planned "to talk about how I thought that the friendships were different," but then realized it was not up to her to make those deductions. She stated, "I was thinking about the friendships I've made and the people I've met, and I was like, 'I would rather ask people about their own friendships'-I thought that was more representative of them."

This was not the case for all students and some, such as Kenna and Joelie, highlighted their participants' words as extensions of their own perspectives without seeking negative examples that might put their findings into question. Other students, such as Noah and Katy, acknowledged being surprised by their findings, but then dismissed them as "strange." Katy's project, for example, focused on what she termed the "pet culture," which related to how she noticed the Montesolens taking their dogs with them everywhere. including to restaurants and workplaces. Katy was surprised to find that each of her participants consistently responded that their pets were their "life" and "reason for being" and it would pain them to leave their dogs at home. These answers "were more intense" than she had anticipated and although she found them to be "sweet," she also thought them somewhat silly. She added, "I mean of course I love my pets, BUT ... " Katy struggled to decenter her own beliefs to value those of her participants and although her project focused on her participants' voices, she still framed her findings from a "American versus Italian" approach where her cultural views were prioritized. 


\section{Art-as-thinking}

Students found the creative process to be a platform for expression and thinking through their work. As per Dewey's ([1934] 2005) theoretical views of art-as-experience, the creation of art presented varied and expanded ways of communicating and thinking beyond the traditional, text-based methods such as essays or blogs. Carolann, for example, stated, "The art-making parts helped me to communicate my point. Instead of just writing an essay, I was able to further explain my stance by creating the piece of art." Charlotte felt her creation helped her go deeper into her thinking more than she would have done if she had only had the written essay. She explained, "If I had just written an essay response, I would have spit out knowledge in the front of my mind and then thrown it away once the course was over." Noah meanwhile added, "I was learning while putting the project together in a way that I didn't really get [otherwise] ... the art component brought out a clearer visual understanding both for me and for viewers."

For James, determining the medium for his artistic representation (see figure 3) proved important in helping him think through what exactly he was trying to communicate. He ultimately chose to craft a ceramic bench as a cultural representation of social space rather than people. He explained, "I made [the bench] because I wanted to visualize ... how social the piazza is ... [the benches] were a social water well that everyone congregates around."

\section{Figure 3. "The benches" by James}

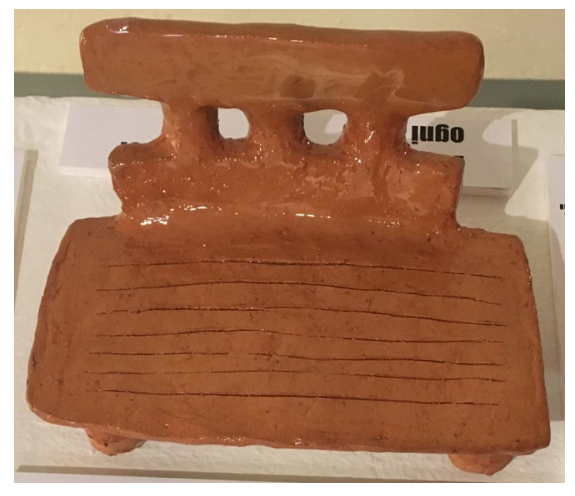

James felt that making a bench avoided the trap of saying "this is Italian culture," and instead it expressed new considerations of what culture can include, i.e. a social space.

Sara described that the artistic process required her "to think more deeply and critically" about culture. She had focused on "personal space" with the assumption that Italians had a much smaller personal space bubble and always spoke closely together. She discovered that while some Italians did seem to have a smaller personal bubble, there were also many who did not. She stated, "They break from the Italian stereotype just as often as we break from the American stereotype." While she was creating her piece, she further considered the role of variation as she thought about how to represent the complexity of personal space. In her graphic design (see figure 4) she first blurred out the graphic of people talking and put it in the background to represent how personal space is not necessarily a conscious decision and that there is a lot of gray area. 
Figure 4. “Personal space” by Sara

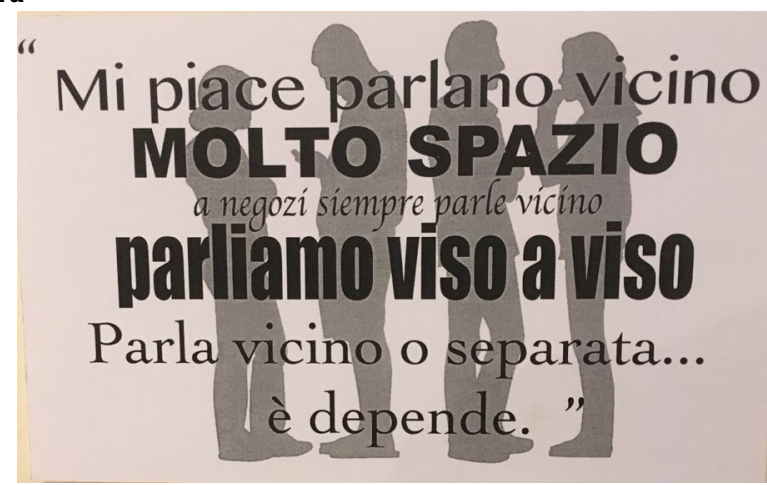

Sara formatted quotes ${ }^{1}$ from her participants in different fonts and bold patterns to illustrate that there was no single stereotype and that personal space depended on the person. Her artistic representation therefore communicates how a cultural concept is not black and white. She concluded that "diving in deeper with 'personal space"' as an actual inquiry process and art project helped her challenge her initial assumptions and stereotypes.

\section{Art-as-representation}

In some cases, however, students moved away from the topics themselves and the projects became a mode for personal documentation of their own interests and of their summer experiences. Kenna, Charlotte, and Joelie found the projects personally fulfilling because they were able to weave their own experiences into them. Kenna additionally expressed how the project presented the opportunity for "painting a picture of our special summer home to our audience." In this way, the art also served as documentation similar to taking a picture and showing it to family and friends. Charlotte likewise stated, "I was able to take everything I loved about Italy and put it into a piece of art."

Joelie chose her topic of "wine culture" because she had enjoyed it as part of her experience in Italy. She explained, "I've found the wine culture in Italy the most interesting as it relates to me since I enjoy it and it's become a part of my daily routine on this trip." Joelie later added that when she learned she could choose her own topic she specifically thought, "I'm doing something fun that will bring some joy to my life." Joelie's cultural inquiry was based on what related to her, what interested her, and what would provide positive memories for her. These participants' comments suggest their projects focused more on what was important to them about their experience in Italy rather than portraying their understandings of cultural hybridity.

\section{DISCUSSION}

As the theme of representation emerged, I began to question how I had framed the project. The very nature of this project invited students to represent a fixed version of their interpretation of culture, which contradicted my learning objectives for the students to see culture as dynamic and could lead to further othering and essentialization (Ladegaard 2020). Scholars have underscored this "crisis of representation" (Clifford and Marcus 1986) from the problematic imagery of "culture" in topics from SA brochures (Caton and Santos 2009) to theme parks (Hoffstaedter 2008). Erickson (2010) 
emphasized that culture varies from person to person and group to group and "thus, no single or determinative human world is a fixed point of reference" (37).

In my self-reflections I realized that I contributed to this problematic issue of representation. Many times, I referred to the art pieces as "artistic representations" and by doing so I therefore inadvertently asked students to represent culture and perhaps even their own experiences. Through my participation in the students' - and hence my own-experiential learning processes, I realized I was asking students to essentialize culture and potentially exploit their participants in the process. Asking for a representation of culture ran the risk of shepherding some students toward cultural consumption, cultural misrepresentation, personal interests, and/or a perpetuation of cultural generalizations through their art pieces.

My intentions for the project were based on Dewey's art as experience for continued thinking and not as a mode for reducing culture to a single concept. As their teacher I was careful to engage students in a more critical dialogue about the complexity and nuances of culture. I continually reiterated the importance of having a critical lens about what they heard and thought about culture to push past stereotypes and cultural reduction. My approach to teaching culture aligned with Erickson's (2010) emphasis on cultural pedagogy: "A way to teach about explicit culture without overgeneralizing about the lifeways of other people is to emphasize the variability of culture within social groups and the continual presence of cultural change as well as cultural continuity across time" (44). Yet, paradoxically, by asking students to then "represent" culture through art, I potentially perpetuated a view of culture as static and as a notion that could be represented in a single piece of art. Therefore, future iterations would benefit from explicit discussion of representation and essentialization.

\section{Can representation be dynamic?}

Given my concerns about representing culture, I then questioned if representation can be dynamic. And, is it possible for students to engage in this type of project with the intended aim of using art as a mode for greater reflective learning? Looking closely at some of the participants' pieces, such as those of Mia, James, and Sara, I argue that it can. Their artworks did not present a static depiction of culture nor did they represent what they wanted to remember from their SA experience. Instead, the pieces showcased a reflection of consciousness and new considerations of what the term culture can include (i.e., social spaces). In this way, the artistic free form promoted culture as a dynamic concept. The creative space and non-linear style of artistic expression (Cahnmann-Taylor and Siegesmund 2017; Rodríguez 2006; Sousanis 2017) has the potential to keep students from making definitive cultural conclusions.

The art pieces also showed it is possible for art to communicate a dynamic consideration of culture through the dialogue that it invites. Eisner $(2002,6)$ stated, "Representation stabilizes the idea or image in a material and makes possible a dialogue with it ... The transformation of consciousness into a public form, which is what representation is designed to do, is a necessary condition for communication." Indeed, James's bench invites such a conversation of culture as a dynamic consideration. It creates movement of thought in the sense that the viewer can visualize different people and groups of people utilizing the bench in different ways at different times for different means. Rosiek (2017) explained this same idea as, "Artistic representations and performances invite people into new holistic relations - conceptual, affective, collective, tactile, material, etc. — with the world in which we 
live. They explore possible modes of being and/or destabilize existing modes of being” (38). Sara's project also promotes a fluid view of culture that depends on the individual. In addition, her graphic design itself figuratively produces a sense of movement in the way she positioned the phrases from small to large with various fonts. Cutting (2002) discussed the ability of artists and scientists to produce motion within static images, whether it be in the form of a painting or a flow chart. In this sense, Sara's art piece does communicate an ongoing consideration of culture through the movement and variety of her visual imagery.

The meaning-making process through art is also evident in how James and Sara arrived at their completed art pieces. The question of the term "representation" might be better addressed by reframing the term itself as Siegesmund (2012) did in his discussion of Dewey and a/r/tography. Siegesmund hyphenated "re-presentation" to express the aim of art as methodology. He stated that it "seeks to capture, record, and artistically re-present moments critical to reclaiming wisdom” (106). With this lens, we can see how some students used their art to 're-present' their meaning-making process. Dewey ([1938] 1998) expressed that art as experience must take us beyond just a felt process, it must involve an experience where we interact with the art and make active connections.

\section{Cultural hybridity}

All 13 of the students showed varying degrees of shifting perspectives with regard to cultural hybridity (Bhabha 1994) particularly across two areas: realizing that what they saw was different from what they had assumed, and realizing that culture is nuanced and individualized. As other scholars have similarly found (Black and Bernardes 2012; Chappell and Chappell 2016), the arts-based inquiry impelled students to play an active role in their own critical thinking about culture rather than just absorbing a static textbook passage. Chappell and Chappell (2016) added that arts-based pedagogies successfully promoted active criticality by asking "students to take part in perspective-taking” (301) rather than learning passively.

The photo observation series stopped time for students, which then allowed them to better notice and process what they were seeing in the images. This finding echoes those of Rodríguez (2006) whose SA participants became more attuned to the landscape and people as was the case of the hot dog vendor who had previously only been part of the backdrop to their SA program. The inquiry process also helped students notice patterns and anomalies that warranted making adjustments to their thinking. The multimodal incorporation of data into their artistic representations further proved important to the experiential learning process because students had to think through their data to best represent what was said and what was observed.

\section{It is a process}

Despite the consciousness-building aspect of the inquiry project, students' developing understandings of cultural hybridity occurred at varying and juxtaposing levels not unlike what some scholars have noted (Mabingo 2019). After implementing a decolonizing pedagogical intervention during SA, MacDonald (2014) concluded students needed continued guidance to challenge their "findings" to arrive at a more complicated understanding of place and people. Likewise, the findings from this study suggest students would have benefitted from increased guidance to challenge them further in their critical thinking. Beyond the SA context, White (2018) likewise concluded that arts- 
based interventions require not only guidance but also explicit focus on the intended goal of the intervention. As per Dewey's theory, education is indeed a continual process and as Chappell and Chappell (2016) also maintained, students will continue to benefit from further experiences and guidance over time in conjunction with arts-based pedagogies.

\section{Recommendations}

The inquiry project is also a process and should be seen as a work in progress. This SoTL study presented the "what works" from Hutchings (2000) typology but can certainly be improved in future iterations. In addition to the above discussion, I further recommend doing increased reflections and project reviews in small groups, whole group, and individually with the educator. In addition, just as we do as qualitative researchers, I would add in a more formal "researcher reflexivity statement" component for the students in the early stages of the project that they would revisit throughout their process. This would help to more explicitly and critically draw their attention to their own positionality and subjectivity and how that impacts data collection and analysis. A greater emphasis on triangulation efforts to help students deepen their understanding of their chosen topics is also important. Although students engaged in daily class discussions of "culture" stemming from a variety of sources outside the project (e.g., films, music, newspapers, and current events), it would be helpful for students to further triangulate their analysis with multiple cultural genres specific to their topics. Finally, students' projects were limited to time and place due to the nature of the short-term program. Nevertheless, it would be prudent to extend the data collection period both in length of time and to other places. For example, comparing coffee shops in different towns or between urban cities and rural villages may yield different findings. This would contribute to a deeper understanding of cultural hybridity and the realization that culture is fluid and changes from place to place and person to person even when in the same cultural context.

\section{CONCLUSION}

I incorporated Dewey's views on experiential learning into practice throughout the course of this pedagogical intervention. The arts-based inquiry framework provided the necessary scaffolding to help students actively participate in their experiences and encourage overall awareness through the acts of noticing and questioning. However, the findings illuminated that students still needed increased guidance throughout their reflective process. In addition to the multiple reflective layers embedded within the project scaffold, I assumed our reflective discussions in class leading up to the end of the projects would be enough, but I now recognize that they were not.

Nevertheless, the implications of this study show that an experiential learning intervention using arts-based pedagogies can begin to disrupt a student's (mis)perception of the singularity of culture, requiring them to confront the naiveté and limitations of such a notion. While there are limitations to this study, such as a single case study conducted over one summer with just 13 US nationals who were the students in my course, the thick description of the project and its findings are relevant across the global context where students of any nationality will benefit from engaging in an arts-based inquiry that works toward shaping a critical SA experience with relation to culture. The inquiry project exposed students to new experiences and interactions within the host community that began the process of 
disrupting their preconceived and fixed notions of what culture is to allow them to begin to see culture through a more critical and hybrid lens.

This study focused on a SA program and is therefore relevant for SA stakeholders, yet the implications are also applicable beyond the scope of the SA field. The thick description of this arts-based inquiry project provides an adaptable framework to guide other educators who may want to incorporate arts-based pedagogies into their curriculum or who may want to focus on the teaching of culture itself. As Bernstein (2018) noted, we do not want to limit our description of the process to "whether something works" and instead want to provide "a rich, thick description, so others can learn from what we are seeing" (118). As other arts-based scholars have also shown (e.g. Chappell and Chappell 2016; White 2018), these findings can be applied to other educational settings and international contexts where the goal is to heighten critical consciousness and through building awareness and thinking through art.

Rhia Moreno is an assistant professor in Advanced Studies and Innovation in the College of Education at Augusta University (USA).

\section{NOTES}

1. Sara transcribed the quotes in Italian herself as an emergent Italian learner. They roughly translate as: "I like talking close," "a lot of space," "In the shops I always talk close," "We talk face to face," "I talk close or separated ... it depends."

\section{REFERENCES}

Adkins, Roger, and Brian Messerly. 2019. "Toward Decolonizing Education Abroad." In Education Abroad and the Undergraduate Experience, edited by Elizabeth Brewer and Anthony C. Ogden, 73-91. Stylus. https://styluspub.presswarehouse.com/browse/book/9781620368275/Education-Abroad-and-theUndergraduate-Experience.

Bain, Steve F., and Lauren E. Yaklin. 2019. "Study Abroad: Striving for Transformative Impact." Research in Higher Education 36: 1-5. https://doi.org/10.1177/0273475307306886.

Barone, Tom, and Elliot W. Eisner. 2012. Arts Based Research. SAGE. https://doi.org/http://dx.doi.org/10.4135/9781452230627.

Bernstein, Jeffrey L. 2018. "Unifying SoTL Methodology: Internal and External Validity." Teaching \& Learning Inquiry 6, no. 2: 115-26. https://doi.org/10.20343/teachlearninqu.6.2.9.

Bhabha, Homi. 1994. The Location of Culture. Routledge. https://doi.org/10.1177/147447409600300117.

Black, Glenda, and Rogerio Bernardes. 2012. "Using Arts-Based Activities to Foster Transformative Learning during a Teaching Practicum in Kenya." Collected Essays on Learning and Teaching 5: 98-102. https://doi.org/10.22329/celt.v5i0.3439.

Breunig, Mary. 2017. "Experientially Learning and Teaching in a Student-Directed Classroom." Journal of Experiential Education 40, no. 3: 213-30. https://doi.org/10.1177/1053825917690870.

Brewer, Elizabeth, Giselda Beaudin, and Michael Woolf. 2019. "Curriculum Integration." Education Abroad and the Undergraduate Experience, edited by Elizabeth Brewer and Anthony C. Ogden, 58-72. Stylus. https://styluspub.presswarehouse.com/browse/book/9781620368275/Education-Abroad-and-theUndergraduate-Experience.

Cahnmann-Taylor, Melisa, and Richard Siegesmund, eds. 2017. Arts-Based Research in Education. 2nd ed. Routledge. https://doi.org/10.4324/9781315305073.

Cai, Wei Wei, and Gopal Sankaran. 2015. "Promoting Critical Thinking through an Interdisciplinary Study Abroad Program." Journal of International Students 5, no. 1: 38-49. https://www.ojed.org/index.php/jis/article/view/441.

Caton, Kellee, and Carla Almeida Santos. 2009. "Images of the Other: Selling Study Abroad in a Postcolonial World." Journal of Travel Research 48, no. 2: 191-204. https://doi.org/10.1177/0047287509332309. 
Chappell, Sharon Verner, and Drew Chappell. 2016. "Building Social Inclusion through Critical Arts-Based Pedagogies in University Classroom Communities." International Journal of Inclusive Education 20, no. 3: 292-308. https://doi.org/10.1080/13603116.2015.1047658.

Chick, Nancy L. 2014. "Methodologically Sound' Under the 'Big Tent': An Ongoing Conversation." International Journal for the Scholarship of Teaching \& Learning 8, no. 2. https://doi.org/10.20429/ijsotl.2014.080201.

Clifford, James, and George E. Marcus. 1986. Writing Culture: The Poetics and Politics of Ethnography. University of California Press.

Cutting, James E. 2002. "Representing Motion in a Static Image: Constraints and Parallels in Art, Science, and Popular Culture." Perception 31, no. 10: 1165-93. https://doi.org/10.1068/p3318.

Dewey, John. 1926. Experience and Nature. Open Court Publishing Company.

Dewey, John. 1933. How We Think. Boston: Heather and Company.

Dewey, John. [1934] 2005. Art as Experience. Perigree.

Dewey, John. [1938] 1998. Experience and Education: The 60th Anniversary Edition. Kappa Delta Pi.

DiFrancesco, Domenic, Linh Khanh Nguyen, Dalton Spurlin, Anjali Dutt, Stacie Furst-Holloway, and Nancy Rogers. 2019. "The Effects of Short-Term Study Abroad on Expanding Students' Culture Perception and Identity." Journal of Higher Education Theory and Practice 19, no. 7: 22-28. https://doi.org/10.33423/jhetp.v19i7.2528.

Eisner, Elliot W. 2002. The Arts and the Creation of Mind. Yale University Press. https://doi.org/10.5860/choice.404405.

Elverson, Cynthia Anderson, and Ruth Klawiter. 2019. “Using Guided Reflection to Link Cultural and Service Learning in a Study Abroad Course." Journal of Professional Nursing 35, no. 3: 181-86. https://doi.org/10.1016/j.profnurs.2018.11.004.

Erickson, Frederick. 2010. "Culture in Society and in Educational Practices." In Multicultural Education: Issues and Perspectives, edited by James A. Banks and Cherry A. McGee Banks, 7th ed., 33-53. Wiley.

Felten, Peter. 2013. "Principles of Good Practice in SoTL." Teaching \& Learning Inquiry. Vol. 1. https://muse.jhu.edu/article/504206.

Goldoni, Federica. 2015. "Preparing Students for Studying Abroad." Journal of the Scholarship of Teaching \& Learning 15, no. 10: 1-20. https://doi.org/10.14434/josotl.v15i4.13640.

Greene, Maxine. 1995. Releasing the Imagination: Essays on Education, the Arts, and Social Change. Jossey-Bass.

Hamilton, Ali, Donald Rubin, Michael Tarrant, and Mikkel Gleason. 2019. "Digital Storytelling as a Tool for Fostering Reflection." Frontiers: The Interdisciplinary Journal of Study Abroad. Vol. XXXI. https://doi.org/10.36366/frontiers.v31i1.443.

Hayes, Jennifer L. (2020). "A Call to Travel: Teaching African American Literature via Study Abroad." In Teaching African American Literature Through Experiential Praxis, edited by Jennifer L. Hayes, 1-5. Palgrave Macmillan. https://doi.org/10.1007/978-3-030-48595-5_1.

Hoffstaedter, Gerhard. 2008. "Representing Culture in Malaysian Cultural Theme Parks: Tensions and Contradictions." Anthropological Forum. https://doi.org/10.1080/00664670802150182.

Hutchings, Pat. 2000. Opening Lines: Approaches to the Scholarship of Teaching \& Learning. Carnegie Foundation for the Advancement of Teaching.

Kramsch, Claire, and Michiko Uryu. 2020. "Intercultural Contact, Hybridity, and Third Space." In The Routledge handbook of language and intercultural communication, edited by Jane Jackson, $2^{\text {nd }}$ ed., 204-18. Routledge.

Ladegaard, Hans J. 2020. "Constructing the Cultural Other: Prejudice and Stereotyping." In The Routledge handbook of language and intercultural communication, edited by Jane Jackson, $2^{\text {nd }}$ ed., 193-203. Routledge.

Lytle, Susan, and Marilyn Cochran-Smith. 1992. "Teacher Research as a Way of Knowing." Harvard Educational Review 62, no. 4: 447-75. https://doi.org/10.17763/haer.62.4.41m3811r1033431n.

Mabingo, Alfdaniels. 2019. "Dancing with the 'Other:' Experiential and Reflective Learning of African NeoTraditional Dances through Dance Education Study Abroad Programs." International Journal of Education and the Arts 20. https://doi.org/10.18113/P8ijea20n2.

MacDonald, Katie. 2014. “(De)Colonizing Pedagogies: An Exploration of Learning with Students Volunteering Abroad." In Globetrotting or Global Citizenship?: Perils and Potential of International Experiential Learning, 
edited by Rebecca Tiessen and Robert Huish, 209-29. University of Toronto Press.

https://doi.org/https://doi.org/10.3138/9781442616707.

Merriam, Sharan B. 1998. Qualitative Research and Case Study Applications in Education. Jossey-Bass Publishers.

Michelson, Kristen, and José Aldemar Álvarez Valencia. 2016. "Study Abroad: Tourism or Education? A

Multimodal Social Semiotic Analysis of Institutional Discourses of a Promotional Website." Discourse and Communication 10, no. 3: 235-56. https://doi.org/10.1177/1750481315623893.

Moak, Stacy C. 2020. "Short-Term Study Abroad Including Service-Learning with Critical Reflection Provides Transformative Experience for Students: Case Study from Kenya." Journal of Service-Learning in Higher Education 10. https://journals.sfu.ca/jslhe/index.php/jslhe/article/view/198.

Moreno, Rhia. 2021. "Disrupting Neoliberal and Neocolonial Ideologies in US Study Abroad: From Discourse to Intervention." Frontiers: The Interdisciplinary Journal of Study Abroad 33, no. 2: 93-109.

Ngyuen, Shelbee, and Joellen E. Coryell. 2015. "Flipping the Script in Study Abroad Participation: The Influence of Popular Culture and Social Networks." Journal of International Students 5, no. 1:23-37. https://www.ojed.org/index.php/jis/article/view/440.

Nieto, Sonia. 2017. Language, Culture, and Teaching: Critical Perspectives. 3rd ed. Routledge. https://doi.org/10.4324/9781315465692.

Pipitone, Jennifer M. 2018. "Place as Pedagogy: Toward Study Abroad for Social Change." Journal of Experiential Education 41, no. 1: 54-74. https://doi.org/10.1177/1053825917751509.

Powers, Samantha L., Nate E. Trauntvein, Cindy L. Hartman, and Robert J. Barcelona. 2020. “Utilizing Culturally Relevant Leisure as an Experiential Learning Tool: Implications for Leisure Studies and Recreation Education." SCHOLE: A Journal of Leisure Studies and Recreation Education, 1-15. https://doi.org/10.1080/1937156x.2020.1760743.

Rennick, Joanne Benham. 2015. "Learning That Makes a Difference : Pedagogy and Practice for Learning Abroad." Teaching \& Learning Inquiry 3, no. 2: 71-88. https://doi.org/10.2979/teachlearninqu.3.2.71.

Rodríguez, K. 2006. "Experiences with Poetry, Pedagogy and Participant Observation: Writing with Students in a Study Abroad Program." International Journal of Education and the Arts 7, no. 1:1-19. http://ijea.asu.edu/v7n1/.

Rosiek, Jerry. 2017. "Art, Agency, and Inquiry: Making Connections between New Materialism and Contemporary Pragmatism in Arts-Based Research." In Arts-Based Research in Education, edited by Melisa CahnmannTaylor and Richard Siegesmund, 32-47. Routledge. https://doi.org/10.4324/9781315305073.

Sharma, Suniti, JoAnn Phillion, and Erik Malewski. 2011. "Examining Preservice Teachers' Critical Reflection for Developing Multicultural Competencies." Issues in Teacher Education 20, no. 2: 9-22. https://www.itejournal.org/issues/fall-2011/Fall 11 TOC.html.

Siegesmund, Richard. 2012. "Dewey through A/r/tography." Visual Arts Research 38, no. 2: 99-109. https://www.muse.jhu.edu/article/500865.

Sousanis, Nick. 2017. "Thinking in Comics: An Emerging Process." In Arts-Based Research in Education, edited by Melisa Cahnmann-Taylor and Richard Siegesmund, 190-99. Routledge. https://doi.org/10.4324/9781315305073.

Strange, Hannah, and Heather J. Gibson. 2017. "An Investigation of Experiential and Transformative Learning in Study Abroad Programs." Frontiers: The Interdisciplinary Journal of Study Abroad 29, no. 1: 85-100. https://doi.org/10.1017/CBO9781107415324.004.

Vande Berg, Michael, R. Michael Paige, and Kris Hemming Lou. 2012. Student Learning Abroad: What Our Students Are Learning, What They're Not, and What We Can Do about It. Stylus.

Varga-Dobai, Kinga. 2018. "Remixing Selfies: Arts-based Explorations of Funds of Knowledge, Meaning-Making, and Intercultural Learning in Literacy." International Journal of Multicultural Education 20, no. 2: 117-32. http://dx.doi.org/10.18251/ijme.v20i2.1572.

White, Jason C. 2018. "See the Dance: Piloting an Arts-Based Intervention in Higher Education." Innovative Higher Education 43, no. 6: 431-45. https://doi.org/10.1007/s10755-018-9440-4. 


\section{(ब) $(1) \Theta$}

Copyright for the content of articles published in Teaching \& Learning Inquiry resides with the authors, and copyright for the publication layout resides with the journal. These copyright holders have agreed that this article should be available on open access under a Creative Commons Attribution License 4.0 International (https://creativecommons.org/licenses/by-nc/4.0/). The only constraint on reproduction and distribution, and the only role for copyright in this domain, should be to give authors control over the integrity of their work and the right to be properly acknowledged and cited, and to cite Teaching \& Learning Inquiry as the original place of publication. Readers are free to share these materials-as long as appropriate credit is given, a link to the license is provided, and any changes are indicated. 